\title{
JUMLAH TOTAL BAKTERI ASAM LAKTAT DAN PH PAKAN CAIR BERBAHAN BIJI ASAM UTUH PADA LAMA FERMENTASI BERBEDA
}

\author{
Redempta Wea1), Bernadete Barek Koten'), Endeyani V. Mohamad ${ }^{3)}$ \\ 1, 2) Jurusan Peternakan, Politeknik Pertanian Negeri Kupang, \\ 3) Jurusan Manajemen Pertanian Lahan Kering, Politeknik Pertanian Negeri Kupang, \\ J. Prof. Dr. Herman Yohanes Lasiana Kupang P.O.Box. 1152, Kupang 85011 \\ Korespondensi: redemptawea136@gmail.com
}

\begin{abstract}
The aims of this research were to determine $p H$ and the total number of lactic acid bacteria from fermented liquid tamarind seed feed. The research materials were tamarind seeds, bran, yellow corn, soybean meal, meat and bone meal, and water. The treatments were: RO: Liquid feed fermentation time (LFFT) of O days; R1: LFFT of 7 days; R2: LFFT 14 days; R3: LFFT 21 days; and R4: LFFT 28 days. Research variables: total number of lactic acid bacteria and $\mathrm{pH}$. The results showed that the total number of lactic acid bacteria increased from $O$ (fermentation time $O$ days) to $5.59 \times 10^{4} \mathrm{CFU} /$ $\mathrm{ml}$ (fermentattion time 14 days) and the $\mathrm{pH}$ decreased from $5.76 \pm 0.11$ to $3.76 \pm 0.05$. It was concluded that fermentation time of up to 14 days causes in the total number of lactic acid bacteria and a decrease in $\mathrm{pH}$.
\end{abstract}

Key Words: Pig feed, nutrient, waste, fermentation.

\section{PENDAHULUAN}

Pakan merupakan biaya produksi terbesar (60-80\%) dari usaha peternakan khususnya peternakan babi. Oleh karena itu dicari bahan pakan inkonvensional yang ketersediaanya banyak dan biaya murah dengan memanfaatkan potensi lokal. Salah satu potensi lokal Nusa Teggara Timur (NTT) adalah biji asam.

Biji asam merupakan limbah hasil pengolahan daging buah asam yang sudah sering diberikan oleh masyarakat NTT sebagai pakan ternak babi baik dicampur dengan bahan pakan lain ataupun sebagai pakan tunggal. Biji asam mengandung protein kasar 13,13\%, serat kasar 6,71\%, dan lemak kasar 4,82\% (Panigrahi et al., 1989). Lebih lanjut dinyatakan bahwa biji asam juga mengandung zat anti nurisi tanin $56,2 \mathrm{~g} / \mathrm{kg}$ bahan kering dan anti tripsin 10,8 g/ kg BK yang paling banyak terletak di kulit biji.

Selain mengandung anti nutrisi, biji asam juga memiliki kulit biji yang keras dan membutuhkan waktu kurang lebih 2 jam untuk mengeluarkan kulit biji dari $1 \mathrm{~kg}$ biji asam utuh dengan cara sangrai dan ditumbuk menggunakan lumpang. Oleh karena itu salah satu teknologi sederhana untuk mengatasi hal itu adalah dengan 
melakukan fermentasi pakan cair. Fermentasi pakan cair merupakan salah satu teknologi yang dilakukan dengan cara mencampurkan semua bahan pakan yang sudah diformulasi sesuai kebutuhan fase hidup ternak kemudian difermentasi baik secara spontan maupun menggunakan fermentor.

Hal ini sesuai hasil penelitian Wea et al., (2020) bahwa pakan cair ternak babi dapat dilakukan dengan cara memformulasikan bahan pakan sesuai kebutuhan hidup fase ternak babi dengan perbandingan campuran bahan pakan dengan air adalah 1:3. Namun lama fermentasi yang optimal dari fermentasi yang dilakukan serta jumlah total bakteri asam laktat (BAL) dan kondisi derajat keasaman atau $\mathrm{pH}$ sebagai akibat kerja BAL belum diketahui. Oleh karena itu tujuan penelitian ini adalah mengkaji jumlah total bakteri asam laktat dan $\mathrm{pH}$ pakan cair berbahan biji asam utuh pada lama fermentasi berbeda.

\section{METODE PENELITIAN}

\section{Lokasi dan Waktu Penelitian}

Penelitian dilaksanakan di laboratorium nutrisi dan makanan ternak Politeknik Pertanian Negeri Kupang pada bulan Agustus 2020.

\section{Jenis dan Sumber Data}

Bahan penelitian berupa biji asam utuh yang diperoleh dari daerah Timor Tengah Selatan (TTS) yang sudah disimpan selama $\pm 2,5$ tahun, tepung jagung kuning, dedak padi, tepung tulang dan daging, bungkil kedelai, dan air. Perbandingan air pakan cair yakni 1:3 (Wea et al., 2020).

\section{Metode Pengumpulan Data}

Prosedur penelitian adalah persiapan alat dan bahan, pengumpulan biji asam dari daerah TTS, penyortiran terhadap benda-benda asing, uji apung (biji asam yang baik adalah yang tenggelam), penimbangan biji asam dan bahan pakan lainnya sesuai perlakuan, pencampuran pakan, pengukuran air sesuai perbandingan, pencampuran air dengan pakan sesuai perlakuan, dan fermentasi sesuai perlakuan (Fermentasi diawali dengan perlakuan dengan lama fermentasi terlama yakni 28 hari seterusnya hingga 0 hari agar pembongkaran hasil fermentasi dilakukan pada harri yang sama). 


\section{Teknik Analisis Data}

Perlakuan yang dicobakan terdiri dari : R0 : Pakan cair lama fermetasi 0 hari/ 0 jam; R1 : Pakan cair lama fermentasi 7 hari; R2 : Pakan cair lama fermentasi 14 hari; R3 : Pakan cair lama fermentasi 21 hari; dan R4 : Pakan cair lama fermentasi 28 hari. Penelitian menggunakan Rancangan Acak Lengkap dengan lima ulangan sehingga terdapat 25 unit percobaan. Komposisi nutrisi bahan pakan yang digunakan sesuia dengan Standar Nasional Indonesia untuk babi pembesaran (grower) ( yakni, kadar air maksimal 14\%, protein kasar minimal 15\%, lemak kasar maksimal 7\%, serat kasarv maksimla 7\%, abu maksimal 8\%, kalsium 0,90-1,20\%, fosfor total 0,60-1,00, energi metabolis minimal $2900 \mathrm{kkal} / \mathrm{kg}$ (Badan Standardisasi Nasional, 2016).

Variabel penelitian berupa total bakteri asam laktat dan derajat keasaman atau $\mathrm{pH}$. Bakteri asam laktat (BAL) yang akan dianalisa kandungan total BAL CFU/ml dengan cara mengencerkan sampel secara berderet yaitu $10^{1}-10^{8}$ (Fardiaz, 1989) sedangkan $\mathrm{pH}$ diukur dengan menggunakan alat pengukur $\mathrm{pH}$ digital.

Data penelitian berupa $\mathrm{pH}$ dianalisis dengan analisis varians menggunakan Rancangan Acak Lengkap (RAL) dan uji lanjut Duncan's (Gaspersz, 1991) sedangkan jumlah total bakteri asam laktat dibahas secara deskriptif.

\section{HASIL DAN PEMBAHASAN}

Fermentasi pakan cair yang dilakukan pada keadaan anaerob menghasilkan perubahan yang disebabkan kerja mikroorganisme fermentasi. Salah satu mikrorganisme yang berkembang pada saat fermentasi adalah bakteri asam laktat. Jumlah total bakteri asam laktat dan kondisi derajat keasaman $(\mathrm{pH})$ akibat kerja mikroorganisme ditunjukkan pada Tabel 1 .

Tabel 1. Jumlah total bakteri asam laktat dan $\mathrm{pH}$ pakan cair berbahan biji asam utuh.

\begin{tabular}{lccccc}
\hline BAL dan pH & \multicolumn{5}{c}{ Lama fermentasi (hari) } \\
\cline { 2 - 6 } & $\begin{array}{c}\text { Fermentasi } \\
\text { O hari (RO) }\end{array}$ & $\begin{array}{c}\text { Fermentasi } \\
\text { hari (R1) }\end{array}$ & $\begin{array}{c}\text { Fermentasi 14 } \\
\text { hari (R2) }\end{array}$ & $\begin{array}{c}\text { Fermentasi } \\
\text { 21 hari (R3) }\end{array}$ & $\begin{array}{c}\text { Fermentasi } \\
\text { 28 hari (R4) }\end{array}$ \\
\hline $\begin{array}{l}\mathrm{BAL} \\
(\mathrm{CFU} / \mathrm{m})\end{array}$ & 0 & $5,58 \times 10^{4}$ & $5,59 \times 10^{4}$ & $4,85 \times 10^{4}$ & $4,58 \times 10^{4}$ \\
\hline $\mathrm{pH}$ & $5,76 \pm 0,11$ a & $4,08 \pm 0,16 \mathrm{~b}$ & $3,76 \pm 0,05 \mathrm{c}$ & $3,66 \pm 0,05 \mathrm{c}$ & $3,64 \pm 0,05 \mathrm{c}$ \\
\hline Keterangan: & $\begin{array}{l}\text { Angka yang diikuti huruf yang sama berarti tidak berbeda nyata pada taraf 5\% Uji Jarak } \\
\text { Berganda Duncan. }\end{array}$
\end{tabular}


Data pada Tabel 1 menunjukkan bahwa semakin lama waktu fermentasi hingga 14 hari menyebabkan peningkatan kandungan $\mathrm{BAL}\left(5,59 \times 10^{4} \mathrm{CFU} / \mathrm{ml}\right)$, namun mengalami penurunan pada lama fermentasi 21 dan 28 hari $\left(4,58 \times 10^{4} \mathrm{CFU} / \mathrm{ml}\right)$. Hal ini dikarenakan fermentasi yang terjadi merupakan fermentasi pakan cair yang menggunakan air. Keberadaan air dalam pakan menyebabkan terjadinya pelunakan dinding sel bahan pakan sehingga proses imbibisi air ke dalam sel pakan menyebabkan bahan pakan menjadi mengembang dan lunak. Hal ini menyebabkan mikroroganisme yang berkembang dalam proses fermentasi menjadi mudah untuk menggunakan nutrien tersedia untuk kehidupannya.

Menurut Lumowa dan Nurani (2014), pada saat proses perendaman akan terjadi fermentasi spontan yang menyebabkan bakteri asam laktat (BAL) akan berkembang dan akan memanfaatkan nutrien tersedia dan menghasilkan asam-asam organik salah satunya asam laktat dan sebagian kecil diubah menjadi asam asetat yang akan menurunkan $\mathrm{pH}$ substrat. Kondisi ini akan menghambat perkembangan mikroorganisme patogen yang merugikan (Despal et al., 2011). Hal senada dikemukakan Lindawati et al., (2015) bahwa lama waktu fermentasi merupakan salah satu indikator tumbuhnya BAL, hal ini dikarenakan pada fase awal fermentasi, mikroba akan melakukan penyesuaian diri terhadap substrat yang ditinggali sehingga menyebabkan perbanyakan sel belum ditekankan dan pada proses adaptasi terjadi proses transpor aktif yang mengeluarkan proton sehingga nutrisi untuk bertahan hidup masih mencukupi. Jika nutrisi kurang tersedia maka jumlah BAL akan menurun. Demikian menurut Rohman et al., (2019), semakin lama waktu fermentasi maka dapat meningkatkan jumlah total BAL.

Berdasarkan Tabel 1 juga diketahui bahwa kondisi derajat keasaman atau $\mathrm{pH}$ substrat mengalami perubahan dari pakan cair tanpa fermentasi hingga lama fermentasi 28 hari. Hasil analisis varians menunjukkan bahwa lama fermentasi berpengaruh sangat nyata $(\mathrm{P}<0,01)$ terhadap $\mathrm{pH}$ pakan cair. Hasil uji lanjut Duncan menunjukkan bahwa terdapat perbedaan nyata $(\mathrm{P}<0,05)$ antara pakan cair tanpa fermentasi dengan lama fermentasi 7, 14, 21, dan 28 hari. Demikian juga antara lama fermentasi 7 hari dengan 14 hari, 21 hari, dan 28 hari. Namun tidak terdapat perbedaan nyata $(\mathrm{P}<0,05)$ antara lama fermentasi 14, 21, dan 28 hari.

Perbedaan ini dikarenakan adanya perbedaan jumlah BAL pada lama fermentasi yang berbeda yang juga akan mempengaruhi $\mathrm{pH}$. Dinyatakan demikian karena 
perubahan $\mathrm{pH}$ semakin menurun sejalan dengan perubahan jumlah total BAL yang meningkat hingga lama fermentasi 14 hari dan menurun pada lama fermentasi 21 dan 28 hari.

Hal ini sesuai pernyataan Suhaidi (2003) bahwa perendaman memberikan kesempatan pertumbuhan bakteri asam laktat sehingga proses pengasamaan berlangsung sebagai akibat aktivitas bakteri asam laktat tersebut. Widowati dan Misgiyarta (2003) menyatakan bahwa fermentasi adalah proses baik secara aerob atau anaerob yang menghasilkan berbagai produk yang melibatkan aktivitas mikroba atau ekstraknya dengan aktivitas mikroba terkontrol serta memiliki berbagai manfaat, antara lain untuk mengawetkan produk pakan, memberi cita rasa atau flavor serta memberikan tekstur tertentu pada produk pangan tertentu.

\section{SIMPULAN}

Lama fermentasi pakan cair hingga 14 hari menyebabkan peningkatan jumlah total bakteri asam laktat dan penurunan $\mathrm{pH}$.

\section{DAFTAR PUSTAKA}

Badan Standardisasi Nasional, 2006. Pakan Babi Pembesaran (Pig Grower). SNI 01-3913-2006.

Despal, Permana I. G., Safarina S. N., dan Tatra A. J., 2011. Penggunaan Berbagai Sumber Karbohidrat Terlarut Air untuk Meningkatkan Kualitas Silase Daun Rami. Media Peternakan, 34 (1): 69-76.

Fardiaz S., 1989. Mikrobiologi Pangan. Departemen Pendidikan dan Kebudayaan. Direktorat Jenderal Pendidikan Tinggi. Pusat Antar Universitas Pangan dan Gizi. Institut Pertanian Bogor.

Gaspersz, V., 1991. Metode Rancangan Percobaan. CV Armico: Bandung.

Lindawati S. A., Sriyani N. L., Hartawan M., dan Suranjaya I. G., 2015. Studi Mikrobiologis Kefir dengan Waktu Simpan Berbeda. Majalah Ilmiah Peternakan. 18 (3): 95-99.

Lumowa, S. V. T dan Nurani I., 2014. Pengaruh Perendaman Biji Kedelai (Glycine Max, L. Merr) Dalam Media Perasan Kulit Nanas (Ananas Comosus (Linn.) Merrill) Terhadap Kadar Protein Pada Pembuatan Tempe. Jurnal EduBio Tropika, 2 (2) 187-250. 
Panigrahi S., Bland B., and Carlaw P. M., 1989. The nutritive value of tamarind seeds for broiler chicks. Animal Feed Science and Technology. 22 (4): 285-293.

Rohman A., Dwiloka B., dan Rizqiati H., 2019. Pengaruh Lama Fermentasi TerhadapTotal Asam, Total bakteri Asam Laktat, Total Khamir, dan Mutu Hedonik Kefir Air Kelapa Hijau (Cocos nucifera). Jurnal Teknologi Pangan. 3 (1) 127-133.

Suhaidi I., 2003. Pengaruh Waktu perendaman Kedelai Dan Jenis Zat Penggumpal Terhadap Mutu Tahu. Digitized by USU digital library.

Wea R., Ninu A. Y., dan Koten B. B.,, 2020. Kualitas Nutrisi dan Anti Nutrisi Pakan Cair Fermentasi Berbahan Biji Asam. Jurnal Peternak Indonesia. 22 (2): 133-140.

Widowati S. dan Misgiyarta. 2003. Efektifitas Bakteri Asam Laktat (BAL) dalam Pembuatan Produk Fermentasi Berbasis Protein/Susu Nabati. Prosiding Seminar Hasil Penelitian Rintisan dan Bioteknologi Tanaman. P 360-373. 